\title{
Student-Initiated Religious Expression after Mergens and Weisman
}

\author{
Christina Engstrom Martin†
}

Imagine a public high school graduation ceremony. The graduates wait expectantly as the valedictorian mounts the podium to give her address. "Fellow graduates, parents, teachers, faculty, and members of the school board," she begins. Suddenly she sneezes. The graduating class speaks as one: "God bless you!"

Although rooted in fact, this story has gained mythical stature. ${ }^{1}$ To some, it illustrates the determination and deviousness of those intent on forcing religion into the public schools. To others, it demonstrates the absurdity in attempting to erase all religious references from public school life. While the story is frequently related as a joke, analyzing the constitutionality of such student-initiated religious expression is no laughing matter.

Few legal issues provoke more controversy than religious expression in the public schools. The ACLU reports that of all the cases it handles, only death penalty and school prayer issues regularly elicit anonymous death threats. ${ }^{2}$ And the Supreme Court's various rulings on religion in public schools, rather than bringing order to the area, have only added confusion to the controversy.

This Comment seeks to dispel the confusion surrounding student-initiated religious expression. Drawing on two recent Supreme Court cases, Board of Education v Mergens ${ }^{3}$ and Lee $v$ Weisman, ${ }^{4}$ this Comment will argue that while the First Amendment's guarantee of free speech generally protects student religious speech in the public school setting, the Establishment Clause prohibits organized religious exercises at public school events unless they are held at events that students voluntarily

$\dagger$ B.A. 1991, Yale University; J.D. Candidate 1995, The University of Chicago.

1 The incident occurred at a high school in Yucca Valley, California, in 1991. The incident gained notoriety after it was reported by Paul Harvey. See Paul Harvey, The Sneeze Heard 'Round the World, San Gabriel Valley Trib (Oct 14, 1991).

2 See Oskar W. McConkie and Michele A. Parish, Is Graduation Prayer Constitutional? Pro/Con, 4 Utah Bar J 18, 19 (1991).

${ }^{3} 496$ US 226 (1990).

1112 S Ct 2649 (1992). 
attend in order to participate in a religious exercise. Section I outlines the Supreme Court's school prayer jurisprudence, concentrating on Mergens and Weisman. Section II explores the range of student-initiated religious expression in the public schools today. Section III analyzes Mergens and Weisman, concluding that these cases, taken together, generally permit speech about religion in the public schools but prohibit organized religious exercises unless student attendance is completely voluntary. Finally, to determine the precise parameters of permissible student religious expression under the Establishment Clause, Section IV applies this distinction-rooted in the differences between speech about religion on the one hand, and actual worship on the other-to various student-initiated religious expression controversies.

\section{The SuPReme COURT'S SCHOOL PRAYER JURISPRUDENCE}

Historically, the Supreme Court has examined religious expression in the public schools with exacting scrutiny. Indeed, the Court has found most forms of religious expression in public schools unconstitutional. In its first school prayer case, Engel $v$ Vitale, the Court struck down a required daily prayer. ${ }^{5}$ In subsequent cases, the Court struck down statutes mandating readings from the Bible and the recitation of the Lord's Prayer at the start of each school day, ${ }^{6}$ requiring the posting of the Ten Commandments in every classroom, ${ }^{7}$ and authorizing a moment of silence for "meditation or silent prayer" at the start of each school day. ${ }^{8}$ More recently, the Court held unconstitutional a graduation prayer conducted at the behest of a middle school principal. ${ }^{9}$

In most of these cases, the Court has found the religious practice unconstitutional after analyzing it under the familiar test from Lemon $v$ Kurtzman. ${ }^{10}$ Under the Lemon test, a statute or practice violates the Establishment Clause if it is motivated by a nonsecular purpose, its primary effect is to advance or prohibit religion, or it fosters excessive government entanglement with religion. ${ }^{11}$ The Lemon test is widely considered to be extraordi-

5370 US 421 (1962).

6 Abington School District v Schempp, 374 US 203 (1963).

7 Stone $v$ Graham, 449 US 39 (1980).

8 Wallace $v$ Jaffree, 472 US 38 (1985).

9 Lee $v$ Weisman, 112 S Ct 2649 (1992).

10403 US 602 (1971).

11 Id at 612-13. 
narily malleable and even hostile to religion, and thus it is hardly surprising that most religious exercises in public schools have failed to pass it. ${ }^{2}$

In the recent case of Lee $v$ Weisman, the Court declined to apply the Lemon test, ${ }^{13}$ yet it still held a graduation prayer at a public middle school unconstitutional. ${ }^{14}$ In Weisman, a high school principal decided that a clergyman would lead a graduation prayer, selected a rabbi, and advised him as to the prayer's content. ${ }^{15}$ The Court concluded that the principal, acting as a state official, had directed the performance of a formal religious exercise and that attendance at this state-sponsored religious activity was "in a fair and real sense obligatory" for students. ${ }^{16}$ Although students need not attend graduation to receive a diploma, a student's "voluntary" absence would require her to "forfeit all of those intangible benefits [of family celebration and community recognition] which have motivated [her] through youth and all her high school years." ${ }^{.17}$ The Court compared the graduation ceremony to a classroom, where the risk of compulsion is high. ${ }^{18}$

12 See, for example, Michael W. McConnell, Accommodation of Religion: An Update and a Response to the Critics, 60 Geo Wash L Rev 685, 685-86 (1992) ("The Lemon test is largely irrelevant or indeterminate when applied to most serious establishment issues."); Comment, A Conservative Struggles with Lemon: Justice Anthony Kennedy's Dissent in Allegheny, 26 Tulsa L J 107, 125 (1990) ("Lemon has the effect of being hostile to religious expressions ...."). The Lemon test has, of course, been severely criticized by several members of the Court as well. In Lee $v$ Weisman, Justice Scalia opined in dissent that "[t]he internment of [Lemon] may be the one happy by-product of the Court's otherwise lamentable decision." $112 \mathrm{~S} \mathrm{Ct}$ at 2685.

In Board of Education of Kiryas Joel Village School District $v$ Grumet, 114 S Ct 2481 (1994), the Court held unconstitutional the New York legislature's creation of a separate school district for the Satmar Hasidim along the boundaries of their exclusively Satmar village. The plurality failed even to mention the Lemon test, leading Justice O'Connor to note with approval that "the slide away from Lemon's unitary approach is well underway." Id at 2500 ( $O^{\prime}$ Connor concurring in part).

The Court has recently held, however, that "Lemon, however frightening it might be to some, has not been overruled." Lamb's Chapel $v$ Center Moriches Union Free School District, 113 S Ct 2141, 2148 n 7 (1993). Lower courts, uncertain of what standard to apply, generally still use the Lemon test. See, for example, Americans United for Separation of Church and State $v$ Grand Rapids, 980 F2d 1538, 1543 (6th Cir 1992); Berger $v$ Rensselaer Central School Corp., 982 F2d 1160, 1169 (7th Cir 1993), cert denied 113 S Ct 2344 (1993); Kreisner v San Diego, 1 F3d 775, 780 (9th Cir 1993); Otway v City of New York, 818 F Supp 659, 662-64 (S D NY 1993). In Grumet, all three lower courts had relied on the Lemon test in deciding the case. $114 \mathrm{~S} \mathrm{Ct}$ at 2515 (Scalia dissenting).

13 Specifically, the Court found it could "decide the case without reconsidering the general constitutional framework by which public schools' efforts to accommodate religion are measured." Weisman, $112 \mathrm{~S} \mathrm{Ct}$ at 2655.

14 Id at 2649.

15 Id at 2652.

16 Id at 2655.

17 Id at 2659.

18 Id at 2660 . See also Engel, 370 US at 430 (holding sponsorship of an official prayer 
To reach its holding, the Court applied a "coercion test" rather than the much-maligned Lemon test. The middle school principal's actions, the Court determined, violated the constitutional principle that the government may not "coerce anyone to support or participate in religion or its exercise, or otherwise act in a way which 'establishes a [state] religion or religious faith, or tends to do so."'19 The Court recognized that a dissenter like the petitioner in Weisman has little choice but to stand respectfully and silently during a graduation prayer. ${ }^{20}$ Such action, the Court noted, indicates participation in the prayer, and "[t]he Constitution forbids the State to exact religious conformity from a student as the price of attending her own high school graduation." ${ }^{21}$ The Constitution forbids the state not only from coercing participation in religious exercises, but also from coercing the mere appearance of participation: "What matters is that, given our social conventions, a reasonable dissenter in this milieu could believe that the group exercise signified her own participation or approval of it."22 The coercion analysis thus asks whether the State has coerced participation or the appearance of participation in a religious exercise.

The Supreme Court has not always ruled against religious expression in the public schools, however. In Board of Education $v$ Mergens, the Court upheld the right of a student prayer group to use school facilities during noninstructional time to the same extent other student groups could use school facilities. ${ }^{23}$ Mergens sheds much light on the interplay between the religion and freespeech clauses of the First Amendment in protecting student religious expression.

In Mergens, high school students brought suit against their school district, which had denied them access to school facilities for their prayer club. ${ }^{24}$ The students sued under the Equal Access Act ("EAA"), which prohibits public schools that allow noncurriculum-related student groups to meet on school premises during noninstructional time from discriminating against any student group on the basis of the religious, political, philosophi-

in the classroom unconstitutional).

19 Weisman, 112 S Ct at 2655, quoting Lynch v Donnelly, 465 US 668, 678 (1984).

20 Weisman, $112 \mathrm{~S} \mathrm{Ct}$ at 2658.

${ }^{21}$ Id at $2658,2660$.

22 Id at 2658.

23496 US 226 (1990).

24 Id at $242-43$. 
cal, or other content of its speech. ${ }^{25}$ The case thus centered around two issues: first, whether the EAA required the school to allow the religious student group to meet on school premises during noninstructional time; and second, if the Act indeed obligated school officials to grant religious groups access, whether the Act violated the Establishment Clause. ${ }^{26}$

The Court answered the first question in the affirmative, finding that under the EAA, the school had created a limited open forum by allowing non-curriculum-related student groups to use the premises. ${ }^{27}$ Once it had done so, the school could not discriminate against the prayer club on the basis of the religious content of its speech. ${ }^{28}$ To the second question-whether construing the EAA so as to require schools to grant religious groups access to school facilities violates the Establishment Clause-the Court replied no. A plurality of the Court concentrated on the effects prong of Lemon and pointed to four features of the EAA in holding that the statute did not have the primary effect of advancing religion.

First, secondary school students were likely to understand that the school did not endorse speech that it merely permitted on a nondiscriminatory basis. ${ }^{29}$ Second, the Act expressly limited the participation of school officials in prayer club meetings and thereby minimized the risk that teachers would become religious role models for students. ${ }^{30}$ Third, student group meetings could take place only during noninstructional time, thus avoiding "mandatory attendance requirements." 31 Finally, the broad spectrum of clubs allowed to use the school facilities counteracted any possible message of official endorsement of the prayer club. ${ }^{32}$

Thus, with Mergens and Weisman the Court has drawn a line between permissible and impermissible religious expression in the public schools. On the one hand, a school may not prohibit a student group from meeting on the same terms as other student groups because of the religious content of the group's

2520 USC \& 4071 (1988).

${ }^{28}$ Mergens, 496 US at 231.

27 Id at $246-47$

28 Id at 248-49.

29 Id at 250-51.

30 Id at 252-53.

31 Id at 251, quoting Edwards v Aguillard, 482 US 578, 584 (1987). As early as Engel, the Court explicitly held that the mere fact that the praying itself is voluntary does not keep a practice from violating the Establishment Clause. See Engel, 370 US at 430.

${ }_{32}$ Mergens, 496 US at 252. 
speech. On the other hand, a school may not organize prayer at a graduation ceremony. The current controversy centers on those cases of student religious expression falling between Mergens and Weisman.

\section{CURRENT RELIGIOUS EXPRESSION ISSUES IN THE PUBLIC SCHOOLS}

The debate over student religious speech at public school events encompasses an ever-increasing range of issues. This Section will catalog both the existing controversies and possible variations thereof. In general, the various types of student religious expression have been divided into two categories: organized prayer $^{33}$ and religious speech that does take the form of a formal religious exercise.

\section{A. Organized Prayer}

The issue of student-organized prayer principally arises in four different contexts: graduation, school athletic events and assemblies, baccalaureates, and "flagpole prayer."

The Court's holding in Weisman-that officially organized prayer at graduation violates the Establishment Clause-prompted many students to organize prayers for their graduations themselves. Predictably, such student-organized graduation prayers have provoked litigation, with mixed results in the lower courts. In Jones $v$ Clear Creek Independent School District, the Fifth Circuit held that the school district did not violate the Establishment Clause by allowing high school seniors to choose student volunteers to deliver nonsectarian, nonproselytizing invocations at their graduation ceremonies. ${ }^{34}$ The court analyzed the school district's resolution under the Lemon test, the endorsement test, ${ }^{35}$ and the Weisman coercion analysis, and found no Establishment Clause violation under any of the three approaches. Comparing the case to both Mergens and Weisman, the Jones court held that "a majority of students can do what the State acting on its own cannot do to incorporate prayer in public high

${ }^{33}$ "Organized prayer" denotes planned group prayer and has no implications for an individual student's right to pray silently at any time she wishes.

34 977 F2d 963, 965 (5th Cir 1992), cert denied, 113 S Ct 2950 (1993).

35 The endorsement analysis asks whether a reasonable person would view the challenged government action as a disapproval of her contrary religious choices. Id at 968 . Justice O'Connor introduced the endorsement test in her opinion in Lynch $v$ Donnelly, 465 US 668, 687-88 (1984) (O'Connor concurring). 
school graduation ceremonies." ${ }^{36}$ In Harris $v$ Joint School District No. 241, the United States District Court for the District of Idaho reached a similar result. ${ }^{37}$ The court emphasized that the Supreme Court's failure to prohibit all graduation prayer, despite recent opportunities to do so, showed that the Court would tolerate some prayer at public school ceremonies. ${ }^{38}$

In contrast to Jones and Harris, the Third Circuit issued an injunction in June, 1993 prohibiting all prayer at a New Jersey high school graduation ceremony even though a majority of students had voted to include it. ${ }^{39}$ Justice Souter, acting as circuit judge, denied the school board's application for review and allowed the injunction to stand..$^{40}$

Such division among the circuits places school boards in a quandry, subject to lawsuits from both students denied the opportunity to hold organized prayer at graduation and students forced to listen to such prayer. ${ }^{41}$ Indeed, the problem is further exacerbated by the possibility that students, intent on holding prayer at graduation, will simply defy prohibitions against prayer. For example, students at one Tennessee high school graduation ceremony stood up en masse and recited the Lord's Prayer. ${ }^{42}$ School administrators are thus caught in a crossfire.

Student-initiated prayer at athletic events or assemblies presents many of the same problems as it does at graduation. It is clear after Weisman that prayer initiated by school administrators violates the Establishment Clause. ${ }^{43}$ Similarly, courts have

36 Jones, 977 F2d at 972.

37821 F Supp 638 (D Idaho 1993).

${ }^{38}$ See id at 643 (noting that the Court declined the opportunity by not reaching the issue in Weisman and by denying certiorari in Jones). Some commentators have also inferred the Court's support for this ruling from its failure to grant certiorari and disturb the ruling. See, for example, Ralph D. Mawdsley and Charles J. Russo, Supreme Court Upholds Religious Liberty: Educational Implications, 84 Educ L Rptr 877 (1993).

${ }^{39}$ See ACLU of New Jersey $v$ Blackhorse Pike Regional Board of Education, Docket No 93-5868 (3d Cir, June 25, 1993) (no opinion issued).

40 Black Horse Pike Regional Board of Education v ACLU of New Jersey, Application No A-92-974 (3d Cir, June 28, 1993) (no opinion issued).

11 Last spring Wayne Oldham, principal of a high school in Westmoreland, Tennessee, received letters from the ACLU and other interested groups indicating that they would sue him if he permitted a student to initiate a public prayer at graduation. School Prayer Gaining Ground in South, NY Times A7 (Feb 21, 1994). Compare Schools Get Around Court's Ban on Prayer, Wash Times A1 (May 22, 1993) (reporting five students sued an Indiana school district for banning prayer at graduation).

${ }^{42}$ ACLU Sued Over Graduation Prayer,PR Newswire (June 8, 1993).

4 Before Weisman, at least one court had reached a similar conclusion. See Jager $v$ Douglas County School District, 862 F2d 824 (11th Cir 1989). In Jager, the court held the practice of beginning public high school football games with a prayer over the loudspeaker 
held it unconstitutional for coaches to lead a team in prayer before a game. ${ }^{44}$ However, the constitutionality of student-initiated prayer at athletic events or assemblies remains an open question.

In the pre-Weisman case of Collins $v$ Chandler Unified School District, the Ninth Circuit held it unconstitutional for a school to permit the Student Council to select a student to lead a prayer at each school assembly. ${ }^{45}$ The court rejected the argument that the assembly prayer was constitutional merely because attendance at school assemblies was optional. ${ }^{46}$ The court instead found it problematic that "Chandler students must either listen to a prayer chosen by a select group of students or forego the opportunity to attend a major school function. ${ }^{27}$ While the court's reasoning sounds remarkably like that of the Supreme Court in Weisman, the fact that the assembly prayer at issue was student-organized cautions against reaching the same conclusion too quickly.

Baccalaureate services present another common type of student-initiated prayer, although one that has rarely reached the courts. In Randall $v$ Pegan, a district court held a baccalaureate service organized in the school auditorium by a nondenominational student group constitutional. ${ }^{48}$ The student group had applied to rent the auditorium and had followed the rental procedure established for other civic, private, or student groups seeking to use school facilities during noninstructional hours. ${ }^{49}$ The Court applied the Lemon test and relied heavily on Mergens for the proposition that once the school created an open forum, it

unconstitutional. The school district argued that the Supreme Court's school prayer cases were inapposite because the pregame invocations took place outside of the classroom, because attendance at football games was entirely voluntary, and because the invocations in question lasted only sixty to ninety seconds. The Court rejected these arguments, and noted that the school district could avoid violating the Lemon test and still fulfill its secular purposes of solemnizing the proceedings by using a secular invocation that did not specifically mention religious beliefs or deities.

4 In Doe v Duncanville Independent School District, 994 F2d 160 (5th Cir 1993), a student on the girls' basketball team brought suit to enjoin the team's coach from leading the team in the Lord's Prayer before and after games and practices. See also Steele $v$ Van Buren Public School District, 845 F2d 1492 (8th Cir 1988) (holding that a band teacher's practice of leading prayer before concerts and rehearsals violated the Establishment Clause).
${ }^{45} 644$ F2d 759 (9th Cir 1981).
48 Id at 761.
47 Id at 762.
465 F Supp 793 (W D NY 1991).
49 Id at 794, 796. 
could not preclude a student group from holding a baccalaureate on the basis of its religious content. ${ }^{50}$

A final example of organized prayer in the public school setting is "flagpole prayer." Flagpole prayer is a nationwide Christian prayer vigil in which students across the country gather around school flagpoles to pray before the school day begins. ${ }^{51}$ A threshold issue in such a situation is whether "See-You-at-thePole" prayer vigils should be considered student initiated for purposes of constitutional analysis. Organizations such as the Southern Baptist Convention, Campus Crusade for Christ, and the Christian Broadcasting Network maintain that such prayer presents no Establishment Clause problem precisely because students both initiate and lead the prayers. ${ }^{52}$ Others are skeptical, calling the movement "a well-choreographed, adult-supervised, funded and implemented enterprise" and charging that "[t]hese children are the lackeys of a well-oiled political machine ....."53

Thus, although Lee $v$ Weisman clearly rules out the possibility of administrator-organized prayer at official school events or activities, the constitutionality of student-organized prayer in similar settings remains unclear. Students might attempt to organize prayers at any number of school functions; the preceding discussion has identified the four settings in which students most regularly attempt to organize and conduct prayer. The principal question courts must confront in such instances is whether the simple fact that the prayer is organized by students renders the prayer constitutional, notwithstanding the fact that the prayer remains associated with an official school event and often involves a captive audience of students. ${ }^{54}$

so Id at 795-96.

${ }^{51}$ See Gayle White, Metro Kids Take Part in Flagpole Prayer Meeting; Students' Actions Praised, Criticized, Atlanta Const B2 (Sept 16, 1993); Editorial, Schools Shouldn't Try to Prevent "Flagpole" Prayer, Newsday 38 (Sept 20, 1993).

${ }^{52}$ See White, Metro Kids Take Part in Flagpole Prayer at B2.

53 Id.

st In the absence of clear guidance from the courts, several southern states have initiated legislative responses to the judicial controversy over student-organized prayer. Such legislative initiatives might themselves raise Establishment Clause concerns, possibly violating the secular-purpose prong of Lemon. See Wallace $v$ Jaffree, 463 US 38 (1985) (holding an Alabama statute authorizing a period of silence in public schools for meditation or prayer unconstitutional because it lacked any secular purpose). This Comment leaves such an analysis to later writers.

Arkansas and Tennessee have passed laws allowing students to lead prayer at graduation ceremonies and other school events. The Tennessee law states that "nonsectarian and non-proselytizing voluntary benedictions, invocations or prayers, which are 


\section{B. Religious Speech by Individual Students}

The religious speech of individual students at public school events, or in the classroom itself, presents Establishment Clause issues distinct from those implicated in the organized prayer context. Religious speech by individual students occurs when a student speaks about religion, distributes religious literature, or displays religious artwork in school. Cases involving such student religious speech arise most frequently when a school district or an individual teacher-seeking to avoid violating the Establishment Clause-prohibits a student from delivering a speech or presentation containing a religious message, and the student asserts a right to deliver the message under the Free Speech Clause of the First Amendment. In most of these cases, courts have found that the school's or teacher's Establishment Clause worries or "legitimate pedagogical concerns" outweigh the student's free-speech rights, and thus permit the restriction of student religious speech.

One common example of student-initiated religious expression occurs when a student speaker, often chosen on the basis of some secular criterion such as grade-point average, wishes to include religious remarks in her speech at a public school event. In Guidry $v$ Calcasieu Parish School Board, the class valedictorian planned to give "thanks to her Savior, Jesus Christ, and exhortations to her classmates that a decision to believe in Jesus was the most important thing in life."55 The principal reviewed her speech and told her she could not give it. In response the student brought suit against the school district so that she might

initiated and given by a student volunteer or student volunteers may be permitted on public school property during school-related noncompulsory student assemblies, schoolrelated student sporting events, and school-related commencement ceremonies." 1993 Tenn Pub Acts 534, \& 1(c), amending Tenn Code Ann § 49-6-1004 (1993). A challenge to this statute is currently moving through the federal courts. See Editorial, Why Our Schools Shouldn't Have a Prayer, Wash Post 8 (Apr 3, 1994).

The Arkansas law amended its Equal Access Act to allow student-planned graduation ceremonies and pregame activities at sports events. Ark Stat Ann § 6-21-202(3) (1993). See also Laurel Shaper Walters, Schools Across US Grapple with Prayer at Graduation after Supreme Court Ruling, Christian Sci Monitor 1 (June 3, 1993).

On April 8, 1994, the Mississippi governor signed a similar bill, amending Miss Code Ann $\&$ 37-13-4 (1993). The Mississippi law allows "non-sectarian and non-proselytizing voluntary benedictions, invocations or prayers, which are initiated and given by a student volunteer" at school-sanctioned events. See Mississippi OKs Student-Led School Prayer, Chi Trib 11 (April 9, 1994). Georgia is also considering similar legislation. See Ronald Smothers, School Prayer Gaining Ground in South, NY Times A12 (Feb 22, 1994).

${ }_{55}$ No 87-2122-LC (E D La, Feb 22, 1989), reported in 9 Religious Freedom Rptr 118 (1989), affd on alternative grounds, Guidry v Broussard, 897 F2d 181 (5th Cir 1990). 
give her valedictory. A magistrate granted summary judgment for the school district, stating that the speech would have the primary effect of advancing religion since allowing the speech to be given, after it had been reviewed, would necessarily signal the school's approval and thus violate the Establishment Clause. ${ }^{56} \mathrm{~A}$ similar situation could arise any time a school allows an individual student to address a group of students at a football game, assembly, or any other school function.

Establishment Clause issues also arise when students attempt to distribute religious literature or messages at public schools. ${ }^{57}$ The concern commonly voiced about such student religious speech-and often used by schools to justify restrictions on it-is that allowing students to proselytize openly by discussing religion or distributing religious materials during school time violates the Establishment Clause by subjecting a captive audience of students to coercive religious speech. ${ }^{58}$ The Seventh $\mathrm{Cir}-$ cuit and the Middle District of Pennsylvania have both rejected such concerns and held school policies that completely prohibit students from distributing religious literature unconstitutional. ${ }^{59}$ At the same time, both courts have ruled that student distribution of religious literature may be subjected to time, place, and manner restrictions in the interests of order and forwarding the school's educational goals. ${ }^{60}$

${ }^{66}$ Guidry, 897 F2d at 182.

s7 Religious speech issues might also arise when students wear clothing inscribed with religious messages. In Redmon $v$ Clay County School Board, for example, an elementary school principal, fearing an Establishment Clause violation, prohibited a student from wearing a t-shirt with the message: "O.K., LAST TIME . . . THIS IS YOUR BRAIN [accompanied by a picture of a brain] THIS IS YOUR BRAIN IN HELL [accompanied by a picture of a brain in a frying pan]." Underneath the picture it read: "ANY QUESTIONS? JOHN 3:16-18." The case settled before going to trial, with the school board allowing students to wear clothing with religious messages as long as those messages were not disruptive. No 91-1080-CTVJ12 (M D Fla 1991), reported in 12 Religious Freedom Rptr 90 (1991).

${ }^{48}$ See, for example, Rethford v Norman Public School System, No CIV-91-234 W (W D Okla 1991), reported in 11 Religious Freedom Rptr 181 (1991). In Rethford, a fifthgrade student brought suit after the administration barred her from reading or discussing the Bible during recess with her friends. The case settled when the school agreed to allow the recess Bible sessions and the student agreed to refrain from communicating her religious views to other students unless they specifically asked. Id.

${ }_{59}$ Hedges $v$ Wauconda School District, 9 F3d 1295, 1303 (7th Cir 1993); Thompson $v$ Waynesboro Area School District, 673 F Supp 1379, 1392 (M D Pa 1989). But see Hemry $v$ School Board of Colorado Springs, 760 F Supp 856 (D Colo 1991) (holding that restrictions on the distribution of a religious newspaper in a high school were appropriate in light of the nature and purpose of the nonpublic forum).

${ }_{\infty}$ See Hedges, 9 F3d at 1300-01; Thompson, 673 F Supp at 1387. 
Other courts, though, have found Establishment Clause and pedagogical concerns sufficient to override students' free speech claims. In DeNooyer $v$ Livonia Public Schools, for example, a second-grade student brought suit against her teacher, alleging that the teacher had violated her rights to free speech and free exercise by refusing to allow her to show a video of herself singing a Christian song in church as part of her "VIP of the Week" presentation. ${ }^{61}$ Under the VIP program (designed to improve students' self-esteem through oral presentations to the class), the teacher chose a different student each week to bring special belongings from home for a type of show-and-tell. The court found the teacher's limitation of the student's speech reasonable because the impact of the religious message of the tape on a second-grade audience constituted a "legitimate pedagogical concern" and because showing a video did not meet one of the objectives of the VIP program, which was to have students make oral presentations. ${ }^{62}$ Because the court held that the teacher's actions did not violate the student's free speech rights, it did not reach the question of whether permitting her speech would have violated the Establishment Clause. ${ }^{63}$

Similarly, the Eastern District of Pennsylvania in Duran $v$ Nitsche held that a teacher's pedagogical concerns were sufficiently important to excuse an infringement on a fifth grader's free speech rights. ${ }^{64}$ The student was required to present an oral report to her class and prepared a report on "the Power of God." Upon learning this, the teacher forced the student to give the report to the teacher alone and prevented her from distributing a survey to classmates about their religious views. ${ }^{65}$ The court found this to be a permissible infringement on the student's right to speak, reasoning that it was "reasonably related to legitimate pedagogical concerns," and that the teacher was justifiably concerned that the material was inappropriate for the students' level of maturity and inadequately researched by the student. ${ }^{66}$ Once

61799 F Supp 744 (E D Mich 1992), aff'd as DeNooyer v Merinelli, 1 F3d 1240 (6th Cir 1993), reh'g denied, 12 F3d 211 (6th Cir 1994), cert denied, 114 S Ct 1540 (1994).

62 Id at 751.

63 Id.

64 780 F Supp 1048 (E D Pa 1991).

6s Id at 1051.

${ }_{66}$ Id at 1054-56. Compare Settle v Dickson County School Board, No 91-0562 (M D Tenn, July 18, 1991). In Settle, a teacher prohibited a ninth-grader from writing an English paper on the life of Christ when the student had been assigned to write about the life of a famous person. The district court granted summary judgment to the school board, and the case is currently being appealed. Settle v Dickson County School Board, No 93- 
again, the court did not reach the Establishment Clause issue presented by the defendant school district.

Finally, the public display of student artwork with religious themes can raise Establishment Clause issues. In Joki $v$ Board of Education of Schuylerville Central School District, the Northern District of New York held that a school's decision to display a student's painting depicting a crucifixion scene violated the Establishment Clause. ${ }^{67}$ The student had painted his oeuvre directly onto the wall of the school auditorium as part of a program allowing students planning careers in art to decorate the school with original artwork. ${ }^{68}$ The school argued that even if the picture seemed religious in nature, the fact that the picture was dimly lit, included several unidentifiable and apparently secular figures, and was surrounded by nonreligious pictures negated any possibility of official endorsement. ${ }^{69}$ The court, however, concluded that the painting had the impermissible primary effect of endorsing Christianity. ${ }^{70}$

\section{MERGENS AND WEISMAN ANALYZED}

While the Supreme Court's jurisprudence may appear contradictory, a close study of the interplay between Mergens and Weisman reveals that the Court relies on two guiding principles to determine the constitutionality of student-initiated religious expression. First, religious exercise is constitutional only if student attendance is voluntary. Second, religious speech represents something altogether different than religious exercise, and merits an extremely high level of protection.

\section{A. Mergens, Weisman, and Voluntary Attendance}

Mergens stands for the principle that once a school has created a public forum for student speech, it cannot restrict such speech on the basis of its religious content. But this principle cannot mean that all the practices the Court has struck down as unconstitutional in the public school setting-prayer recited over

6207 (6th Cir 1994). The facts of the case are reported in 11 Religious Freedom Rptr 347 (1991).

67745 F Supp 823 (N D NY 1990).

68 Id at 824 .

69 Id at 829-30. Pictures of an American flag and a Revolutionary War scene surrounded the disputed artwork.

70 Id at 831 . 
the loudspeaker, posting of the Ten Commandments, graduation prayer-become constitutional when organized by students.

This is true for two reasons. First, students have no general right to speak whenever and however they wish in the public school setting. The Court has held that student conduct that "for any reason . . . materially disrupts classwork or involves substantial disorder or invasion of the rights of others is, of course, not immunized by the constitutional guarantee of freedom of speech." The Mergens principle therefore applies only where the school has created an open forum. When the school does not normally permit student speech, the school need not permit student religious speech. Put another way, if only school administrators typically use the school loudspeaker, and they do not ordinarily allow students to use it, the school does not impermissibly interfere with student speech rights by refusing to allow students to speak about religion over the loudspeaker.

Second, and more controversially, Weisman actually curtails students' free speech in certain instances because that case holds that no student may be subjected to a religious exercise as a condition of attending a school event. Recognizing this second proposition requires an elaboration of the reasoning behind the Court's decision in Weisman.

The Weisman Court relied on familiar principles in holding the graduation prayer at issue unconstitutional. The Court analyzed the constitutionality of the graduation prayer according to criteria very similar to those it employed in Mergens. First, the Court found that-unlike the situation in Mergens-the school in Weisman did not merely permit the rabbi's speech on a nondiscriminatory basis. Rather, the principal chose the rabbi, asked him to pray, and dictated the content of his prayer. Thus, the risk that students would understand that the school endorsed the rabbi's speech was very high. ${ }^{72}$ Second, teachers and administrators were heavily involved in the graduation ceremony in Weisman: "At a high school graduation, teachers and principals must and do retain a high degree of control over the precise contents of the program, the speeches, the timing, the movements, the dress, and the decorum of the students." ${ }^{.73}$ Third, whereas in

71 Tinker $v$ Des Moines Independent Community School District, 393 US 503, 513 (1969). In Tinker, the Court held that a school rule prohibiting students from wearing black armbands to protest the Vietnam War violated the students' free speech rights.

72 Indeed, the concurring opinions of both Justice Blackmun and Justice Souter found that the school had endorsed the rabbi's prayer.

$73112 \mathrm{~S} \mathrm{Ct}$ at 2660. 
Mergens the wide variety of student clubs using school facilities effectively rebutted any notion that the school endorsed a religious club by permitting it to use school facilities, ${ }^{74}$ in Weisman there was no broad spectrum of graduation speech to counteract the appearance that the school endorsed the religious prayer at graduation. Finally, the Weisman Court found attendance at graduation to be "in a real sense obligatory." $\mathrm{\text {Agraduationcer- }}$ emony, the Court noted, was the equivalent of instructional time, at which attendance is compulsory. ${ }^{76}$

Understanding what the Weisman Court meant in finding that attendance at graduation is "obligatory" is necessary in order to apply Weisman to subsequent cases. Attendance at graduation is clearly not "obligatory" in the same way that compulsory education laws make classroom attendance obligatory. Failure to attend graduation will not be met with official sanction. All a student forfeits by not attending her graduation are the benefits of actually attending the ceremony. Such attendance is "voluntary" as the word is commonly understood. The Court therefore must have meant something different when it labeled attendance at graduation "obligatory."

The Weisman Court confronted this issue, stating that " $[t]$ he Constitution forbids the State to exact religious conformity from a student as the price of attending her own high school graduation."77 This does not only mean that a student cannot be forced to pray at graduation. Since its first school prayer case, the Court has insisted that the fact that actually praying is voluntary does not render permissible an otherwise unconstitutional prayer. ${ }^{78}$ Thus, in Weisman, the volition in question is not merely the volition to attend an event like graduation, but the volition to attend an event at which a religious exercise will be conducted.

This understanding of what Weisman meant by "obligatory" finds further support in Tinker $v$ Des Moines Independent Community School District. ${ }^{79}$ There, the Court ruled that schools may limit student speech where that speech causes "substantial

74 See Lamb's Chapel v Center Moriches Union Free School District, 113 S Ct 2141, 2146-47 (1993) (holding that once a school district opened a school for general after-hours use, a ban on use for religious purposes violated the Free Speech Clause).

${ }^{76}$ Weisman, $112 \mathrm{~S}$ Ct at 2655.

76 Id at 2659.

77 Id at 2660.

78 See Engel, 370 US at 430 ("Neither the fact that the prayer is denominationally neutral nor the fact that its observance on the part of the students is voluntary can serve to free it from the limitations of the Establishment Clause . . . .").

79393 US 503 (1969). 
disorder" in the school or impinges on other students' rights. ${ }^{80}$ Prohibiting religious expression or prayer at events where student attendance is "obligatory" amounts to limiting student religious speech where it is likely that other students' rights will be infringed. ${ }^{81}$

Thus, Mergens and Weisman allow religious exercises in the public schools where students knowingly and willingly attend the event as a religious exercise. The cases prohibit religious exercises where attendance is obligatory-that is, where students cannot be said to be attending the event in order to engage in a religious exercise. The three remaining Mergens criteria-whether students will understand that the school permits the religious speech on a nondiscriminatory basis, whether teachers and administrators are involved and to what extent, and whether a broad spectrum of speech counteracts the appearance of endorsement of the religious speech-qualify this distinction by imposing further conditions on school prayer. Even if a court finds attendance at the religious exercise voluntary, it may use the other three criteria to invalidate a practice. For example, a student prayer club at which attendance is entirely voluntary may still be held unconstitutional if a teacher organizes and leads it.

\section{B. Differentiating Between Religious Exercise and Religious Speech}

The Court's emphasis on whether students voluntarily attend religious exercises at public school events signals its implicit understanding that a religious exercise, such as prayer, differs from speech about religion and thus warrants different treatment under the Establishment Clause. The Court has repeatedly recognized this distinction by emphasizing that various practices are unconstitutional because they amount to "religious exercises." In Engel $v$ Vitale, for instance, the Court based its decision on the high risk of coercion surrounding religious activity in the public school setting. ${ }^{82}$ In Abington School District $v$ Schempp, where

80 Id at 513.

81 Note that the "voluntariness" requirement for religious exercises in the public schools is contrary to the general free speech principle that the so-called heckler's veto does not justify curtailing a speaker's right. See Terminiello $v$ City of Chicago, 337 US 1 (1949). See also Doe v Small, 964 F2d 611, 630 (7th Cir 1992) (Easterbrook concurring) ('If hecklers cannot silence political speech in a public forum, obtuse observers cannot silence religious speech in a public forum.").

$82370 \mathrm{US}$ at 431 . 
the Court held unconstitutional a daily Bible reading in Pennsylvania public schools, the Court agreed with the trial court's finding that "such an opening exercise is a religious ceremony" and thus unconstitutional. ${ }^{83}$ In Weisman, the Court found it impermissible that "[s] tate officials direct[ed] the performance of a formal religious exercise ...."

Speech about religion differs fundamentally from religious exercise in two important ways. First, common social understanding dictates that merely listening to a religious exercise is participating in that exercise. As the Weisman Court noted, a dissenting student has no meaningful way to signal her nonparticipation in a graduation prayer, barring a conspicuous protest. To sit or stand silently is to participate in the prayer. ${ }^{85}$ A religious exercise may be compared to a political rally; listening is participating, whether or not the listener agrees with the speaker or engages in the same mental processes as the speaker. It makes no sense to say that 500 people attended the rally, but only 450 were actually participating. Everyone who attends a rally is participating. Similarly, listening to a prayer at graduation constitutes participation in a religious exercise, and the school may not require such participation as a condition of graduation.

Second, speech about religion is accessible to outsiders in a way that a religious exercise is not. A religious exercise excludes all dissenters from the discussion by leaving no room for response. ${ }^{86}$ This distinction between religious speech and religious exercise parallels John Rawls's concept of public reason, which requires that political decisions refer to widely accepted principles of political justice rather than to individuals' private religious or moral beliefs.

What public reason asks is that citizens be able to explain their vote to one another in terms of a reasonable balance of public political values, it being understood by everyone that

83 374 US 203, 223 (1963) (emphasis added).

84 $112 \mathrm{~S} \mathrm{Ct}$ at 2655 (emphasis added).

85 Id at 2658 ("There can be no doubt that for many, if not most, the act of standing or remaining silent was an expression of participation in the Rabbi's prayer. That was the very point of the religious exercise.").

${ }_{86}$ Professor Greene uses similar reasoning to argue against allowing legislatures to enact legislation for the express purpose of advancing religious values. Abner S. Greene, The Political Balance of the Religion Clauses, 102 Yale L J 1611, 1620 (1993) ("II]t is proper to insist that law be grounded expressly in sources of value accessible to citizens as citizens, not merely to those citizens who happen to share a faith in a separate, extrahuman source of authority."). 
of course the plurality of reasonable comprehensive doctrines held by citizens is thought by them to provide further and often transcendent backing for those values. ${ }^{87}$

The Rawlsian duty to appeal to political values that all can understand also implies "the duty to adopt a certain form of public discourse." ${ }^{38}$ Likewise, the prohibition on religious exercises at public school events constitutes a duty to adopt a certain form of public discourse. Religious exercises necessarily involve one-sided discourse on comprehensive religious doctrines that not all students share. Such exercises fail to provide a forum for discourse in which every student can participate. When someone says "I believe $X$," giving a statement of personal belief, a nonbeliever can respond, "I do not believe X, I believe Y." A sacred, religious exercise like prayer admits of no such response because it demands group participation and silences dissent. ${ }^{89}$ As the Court noted in Weisman, the dissenting student could not respond to the prayer but could only maintain a respectful silence.

Because religious exercise usually admits of no response from nonbelievers, it can cause greater harm than speech about religion. As Justice O'Connor noted in another context, the religious exercise conducted under the auspices of the state "sends a message to nonadherents that they are outsiders, not full members of the political community ...." ${ }^{m 0}$ Moreover, the risk of alienation and coercion increases where schoolchildren are concerned. ${ }^{91}$

${ }^{87}$ John Rawls, Political Liberalism 243 (Columbia, 1993). Rawls advocates a concept of public reason that requires political decisions to be made by reference to accepted principles of political justice rather than by reference to individuals' comprehensive religious or moral doctrines that are not shared by all. Rawls observes that "[a]s far as possible, the knowledge and ways of reasoning that ground our affirming the principles of justice and their application to constitutional essentials and basic justice are to rest on the plain truths now widely accepted, or available, to citizens generally." Id at 225.

${ }_{83}$ Id at 242.

89 Professor Laycock suggests that prayer often enters into an otherwise secular public ceremony "precisely because some people want a symbolic affirmation that government approves and endorses their religion, and because many of the people who want this affirmation place little or no value on the costs to religious minorities." Douglas Laycock, Summary and Synthesis: The Crisis in Religious Liberty, 60 Geo Wash L Rev 841, 844 (1992).

${ }^{\circ}$ Lynch v Donnelly, 465 US 668, 688 (1984) (O’Connor concurring).

${ }^{91}$ See Weisman, $112 \mathrm{~S} \mathrm{Ct}$ at 2658 ("[T]here are heightened concerns with protecting freedom of conscience from subtle coercive pressure in the elementary and secondary public schools."). See also Schempp, 374 US at 307 (Goldberg concurring); Edwards $v$ Aguillard, 482 US 578, 584 (1987); Mergens, 496 US at 261-62 (Kennedy concurring). 
Speech about religion, on the other hand, encourages open discussion and allows nonbelievers to participate if they so choose. Public schools should expose students to different beliefs and practices, religious and otherwise, in order to promote the tolerance and multiculturalism necessary to live in our increasingly pluralistic society. ${ }^{92}$ Certainly one of the greatest benefits of a public school education is the heterogeneity of its students. The religion clauses should not be read to require homogeneity by silencing cultural and religious differences.

At the same time, however, no public school should require students to attend or participate in a religious ceremony. Compulsory attendance at a Catholic religious exercise, for example, would silence cultural and religious differences as surely as a rule prohibiting students from mentioning religion at all. Just as it is undesirable to force religious expression out of the public sphere entirely, it is equally undesirable to conduct religious exercises that celebrate certain beliefs as part of public school events attended by students who do not share those beliefs. There is a significant difference between learning about various religious views through speech about religion (for example, a classmate giving a report on the importance of religion in his life, or about the life of Mohammed) and compelled presence at or participation in a religious exercise to which students are unable to object..$^{93}$

C. Objections and Answers to the Religious Speech-Religious Exercise Distinction

The religious speech-religious exercise distinction made a brief appearance in Supreme Court jurisprudence in Justice White's dissenting opinion in Widmar $v$ Vincent. ${ }^{94}$ In Widmar, the Court held that a public university that had established an open forum for student groups could not exclude a student religious group on the basis of the religious content of its speech..$^{95}$ The majority rejected Justice White's argument that "religious

92 See Amy Gutmann, Democratic Education 287 (Princeton, 1987).

93 Along the same lines, one might argue that schools should not require students to participate in controversial secular exercises. For example, requiring children to write pro-environment "letters to the editor" coerces their participation in a political exercise, perhaps violating their beliefs in a much different way from merely presenting a proenvironment view during science class.

94454 US 263 (1981).

95 Id at 277. In Mergens, the Court held that in passing the Equal Access Act, "Congress extended the reasoning of Widmar to public secondary schools." 496 US at 235. 
worship" is not speech generally protected by the free speech guarantee of the First Amendment. ${ }^{96}$

The Widmar majority merely held that the distinction had no bearing on whether a university could prohibit a student group from using university facilities based on the content of the group's speech. The analysis proposed in this Comment reaches the same result: Whether a student religious group wishes to discuss religion or to pray together does not affect the Mergens equal-access principle that a school may not discriminate against such speech on the basis of its religious content. In this context, worship gets the same protection as speech about religion.

The Court has, however, distinguished between religious exercise and speech about religion where the audience is a captive one. For example, Weisman held that the Establishment Clause forbids a school from making attendance at a religious exercise a condition of attending a public school event. ${ }^{97}$ Hence, the distinction remains valid as long as it can avoid the problems pointed out by the Widmar Court.

The religious speech-religious exercise distinction has been criticized on several fronts. First, the distinction presents an obvious line-drawing problem. Not every religious expression falls neatly into a category of either speech or worship. On the most basic level, worship often takes the form of speech. And problems persist even if a line can be drawn between communicating about religion with other humans and communicating with a deity. Religious music or art might be thought of as either speech with a religious theme or worship. Furthermore, religious people might categorize such art or music differently from nonreligious people. For example, a religious student might consider singing religious music a religious exercise, whereas a nonreligious student might consider it speech about religion and not a religious exercise.

The answer to this objection must be that any analysis of religious speech in the public schools under the First Amendment will present some line-drawing problems. The existence of such problems at the margin does not render the entire analysis faulty. Most religious speech can in fact be easily categorized as either worship or speech about religion.

The second objection to the religious speech-religious exercise distinction builds upon the first: even if the line can be 
drawn by someone, courts lack the competence to make the distinction. Such line drawing would require courts to "inquire into the significance of words and practices to different religious faiths, and in varying circumstances," and would thus impermissibly entangle the State with religion. ${ }^{98}$ The Court, however, constantly distinguishes between what is religious and what is nonreligious. ${ }^{99}$ Since Reynolds $v$ United States, in which the Court upheld the conviction of a Mormon for bigamy, ${ }^{100}$ the Court has distinguished between religious beliefs and religious acts. That distinction clearly requires inquiry into the significance of words and practices to different faiths and in varying circumstances. Furthermore, the Court has repeatedly singled out religious exercises at public school events as unconstitutional without limiting students' rights to speak about religion at such events. ${ }^{101}$

A third objection to the religious speech-religious exercise distinction lies in the fear that students may use class activities and assignments to proselytize, possibly as part of an organized effort to inject religion into the public schools. ${ }^{102}$ Some have even argued that student proselytizing violates the Establishment Clause because parents who send their children to public schools have a right to expect instruction free from religious indoctrination. ${ }^{103}$ But the Establishment Clause already pro-

${ }_{98}$ Widmar, 454 US at $269 \mathrm{n}$ 6. Professor Laycock similarly argues that allowing school officials to differentiate between religious speech and worship in monitoring private meetings of student religious groups would breed "censorship of the most intrusive and offensive kind." Douglas Laycock, Equal Access and Moments of Silence: The Equal Status of Religious Speech by Private Speakers, 81 Nw U L Rev 1, 57 (1986).

99 For example, the Court has repeatedly decided whether crèches in various public displays constitute religious symbols. See Lynch, 465 US 668; County of Allegheny $v$ ACLU, 492 US 573 (1989); American Jewish Congress v Chicago, 827 F2d 120 (7th Cir 1987); ACLU v Birmingham, 791 F2d 1561 (6th Cir 1986); Smith $v$ County of Albemarle, Virginia, 895 F2d 953 (4th Cir 1990); Burelle v City of Nashua, 599 F Supp 792 (D NH 1984). See generally Comment, Private Religious Displays in Public Fora, 61 U Chi L Rev 253, 257-59 (1994).

${ }_{100} 98$ US 145 (1878).

101 See text accompanying notes 71-84.

102 See generally Eugene C. Bjorklun, Show and Tell, the Establishment of Religion, and Freedom of Speech, 84 Educ L Rptr 601 (1993). The comments of one prominent advocate of religion in the public schools lend credence to the Supreme Court's expressed fear of proselytization in the public schools: "Our purpose must be to spread the gospel on the new mission field the Lord has opened-public high schools." See Rob Boston, American Public Schools: Mission Field USA? 45 Church \& State 8 (1992), quoting Jay Alan Sekulow, general counsel of Christian Advocates for Serving Evangelism. See also Ruti Teitel, When Separate is Equal: Why Organized Religious Exercises, Unlike Chess, Do Not Belong in Public Schools, 81 Nw U L Rev 174 (1986).

${ }^{103}$ Teitel, $81 \mathrm{Nw}$ U L Rev at 178-79, 182-83 (cited in note 102). 
tects parents' rights by prohibiting teachers from proselytizing or endorsing religion in any way. Student proselytizing, on the other hand, is protected by the Free Speech Clause, just as students' attempts to convince other students to join the Democratic Party constitute protected speech. Mergens requires that speech about religion be treated like any other subject under the First Amendment's guarantee of free speech. Allowing students to proselytize also promotes tolerance and diversity in the public schools, while still leaving room for response and discussion from students holding different beliefs.

Furthermore, critics may overstate concerns about student proselytization. Students generally have a limited opportunity to speak freely in the public school setting because so much of their time is strictly regulated for educational and disciplinary purposes. Schools already place time, place, and manner restrictions on activities like handing out religious literature and may also impose more general rules such as prohibiting talking in the halls. ${ }^{104}$ Additionally, teachers can avoid turning the classroom into a "tent revival" by carefully tailoring assignments and activities to educational objectives.

The fourth objection some commentators have advanced is that mere exposure to ideas hostile to students' religious beliefs violates the Establishment Clause, because such exposure improperly influences their beliefs, while their respectful silence might be taken as assent to these hostile ideas. ${ }^{105}$ However, it is neither possible nor desirable to shield students from all "hostile ideas" in the public schools. Nearly every idea could be "hostile" to some students' religious, philosophical, or political beliefs. ${ }^{106}$ Furthermore, teaching such hostile ideas might be educationally necessary and appropriate in certain situations. It would be difficult, for example, to study the Holocaust without discussing Nazism, or study the Pilgrims without discussing Puritanism. As an alternative to banning "hostile" speech, schools should present it in a form that gives students an opportunity to

${ }^{104}$ For cases treating time, place, and manner restrictions on distributing religious literature, see Hedges $v$ Wauconda School District, 9 F3d 1295, 1300-01 (7th Cir 1993). See also Tinker, 393 US at 513.

${ }^{105}$ See generally George W. Dent, Jr., Religious Children, Secular Schools, 61 S Cal L Rev 863 (1988).

${ }^{106}$ See, for example, Mozert $v$ Hawkins County Board of Education, 827 F2d 1058, 1070 (6th Cir 1987) (holding that exposure to textbooks that the plaintiffs believed taught, among other things, evolution, moral relativism, internationalism, witchcraft, and idolatry, did not violate the students' free exercise rights). 
respond, insuring that religious speech does not "improperly influence" students' beliefs.

Of course, even religious expression can be coercively and impermissibly used in the public school setting. For example, a teacher could exhort students to use their free time to think about the importance of Jesus in their lives. Or, less blatantly, a teacher could favor students who attend church or who profess a belief in God. Any of these are clearly impermissible endorsements of religion by a state actor. However, individual student religious speech, unregulated as to content by the teacher, does not pose the same difficulty.

A final objection to the religious speech-religious exercise distinction is that it might allow religious groups to dominate public discourse. However, the Court indicated in Widmar that its Establishment Clause and Free Speech analyses might differ if an open-forum policy resulted in religious groups dominating the forum: "At least in the absence of empirical evidence that religious groups will dominate [the university's] open forum, ... the advancement of religion would not be the forum's 'primary effect."'107 Thus, the Mergens principle that affords the same First Amendment protection to student religious speech as it does to other student speech may find an exception in cases where religious speech dominates the forum in question.

\section{APPLYING THE RELIGIOUS SPEECH-RELIGIOUS EXERCISE DISTINCTION}

The religious speech-religious exercise distinction provides parameters for permissible student religious expression in the public school setting. Religious exercises, whether organized by school officials or by the students themselves, are permissible only when student attendance is voluntary. When attendance is not voluntary, the risk that students will be coerced into participating in religious practices is too great. However, religious speech does not engender the same concerns; rather, religious speech must be accorded the same protection other student speech receives in order to promote discussion and tolerance in the public schools.

107454 US at 275. In his concurrence in Mergens, Justice Marshall voiced similar concerns about possible Establishment Clause violations where a religious student group is the only controversial or advocacy-based student group at a particular school. See 496 US at 266. 


\section{A. Organized Prayer}

Any type of organized religious exercise at a public school event-be it a graduation ceremony, assembly, or football game-violates the Establishment Clause. ${ }^{108} \mathrm{~A}$ vote by a majority of the students to include prayer at such an event has the same constitutional infirmities as would an administration decision. Indeed, Weisman itself noted that a majority preference could not rehabilitate an otherwise unconstitutional practice: "While in some societies the wishes of the majority might prevail, the Establishment Clause... rejects the balance urged upon us." 109

The Establishment Clause is concerned with the coercive effects of the appearance of government endorsement of religious preferences. Beginning with Engel, the Court has continually warned that "[w]hen the power, prestige, and financial support of government is placed behind a particular religious belief, the indirect coercive pressure upon religious minorities to conform to the prevailing, officially approved religion is plain."110 The coercion test proffered by Weisman addresses the same problem.

The Court has not held that students must be free from all conceivably coercive pressure under the Establishment Clause. In Mergens, the Court noted that "[t]o be sure, the possibility of student peer pressure remains ...."111 Thus, the "coercion" in the coercion test is not the ordinary peer pressure adolescents and others endure daily. Rather, the coercion to worry about is a kind of super social pressure brought about by the appearance of state endorsement of the majority's preference.

The coercive social pressure caused by official sanction of the majority's religious beliefs also exists when students vote to include prayer. First, the appearance of official sanction is present whenever prayer is conducted at a public school event. The Eleventh Circuit has held that when a religious invocation is given over a sound system controlled by school officials at a schoolsponsored event in a school-owned facility, the "conclusion is inescapable that... the school endorses the religious invoca-

${ }^{108}$ Attendance at assemblies and athletic events is even more "voluntary" in the common use of that word than attendance at a graduation ceremony. Nonetheless, such attendance is still not voluntary under the Weisman standard: all students do not attend assemblies or athletic events for the purpose of attending a religious exercise.

$109112 \mathrm{~S} \mathrm{Ct}$ at 2660.

11 Engel, 370 US at 431.

111496 US at 251. 
tion."112 Second, the school board or the administration often initiates and frames such debates. ${ }^{113}$ Furthermore, the fact that the administration carries out the students' decision to include prayer at graduation is telling, for students' preferences alone do not typically dictate school policy. If a majority of students voted to sacrifice 100 bats at graduation, the administration would not likely honor this preference. These concerns render a majority student vote insufficient to quell the fear of coercion when majority religious preferences are backed by official sanction. Organized religious exercises at public school events, whether initiated by school administrators or by students, remain impermissible under Weisman because they force dissenting students to listen to, and thus to participate in, prayer as a condition of attending graduation ceremonies, assemblies, or athletic events. ${ }^{114}$

A more difficult case arises when an individual speaker, like the valedictorian or an outside speaker chosen by the students, wishes to conduct a prayer as part of her speech. In this situation, the Mergens guarantee of equal access for religious speech and the Weisman prohibition on obligatory religious exercises appear to conflict. The conflict is actually illusory. The situation is not exactly analogous to the typical equal access case because graduation is not an open forum in the Mergens sense. Only one student gets to speak, and no broad spectrum counteracts the effects of her speech. Additionally, the event itself constrains what a speaker may express and how she may express it, since

112 Jager v Douglas County School District, 862 F2d 824, 831 (11th Cir 1989).

113 "This was not student-initiated. This was school board- and school superintendentinitiated ... . The school [system] devised a ballot [for the voting] ... ." Kristan Metzler, Judge Bars Loudon Graduations Prayers; Rules Plans Were Not Students' Idea, Wash Times Al (June 19, 1993), quoting Judge Albert Bryan. Gearon v Loudon County Schools, No 93-730 (E D Va, June 18, 1993).

${ }_{11}$ Under this analysis, Jones v Clear Creek Independent School District, 977 F2d 963 (5th $\mathrm{Cir} 1992$ ), which permitted graduation prayer approved by student vote, was wrongly decided. Furthermore, alternative schemes for determining when public school events may include prayer are also unconstitutional under this analysis because such schemes subject dissenting students to religious exercises as a condition of attending a public school event. See, for example, Christian M. Keiner, A Critical Analysis of Continuing Establishment Clause Flux as Illustrated by Lee v. Weisman and Graduation Prayer Case Law: Can Mutual Tolerance Reconcile Dynamic Principles of Religious Diversity and Human Commonalty? 24 Pac L J 401 (1993) (proposing that school administrators choose a student randomly from a pool that includes all of the denominations with members in the student body and allow that student to give whatever type of invocation he wishes, religious or otherwise, at graduation). See also Arnold H. Loewhey, School Prayer, Neutrality, and the Open Forum: Why We Don't Need a Constitutional Amendment, 61 NC L Rev 141 (1982) (proposing that the school day begin with a philosophical recitation chosen or composed by a different student each day). 
common social understanding to a large extent dictates which topics belong in a graduation speech. Individual speakers may express themselves only within narrow parameters. Furthermore, the school retains ultimate control over who speaks at graduation. A school is not constitutionally required to allow a Grand Wizard of the $\mathrm{Ku}$ Klux Klan to speak on white supremacy even if a majority of students voted for him as their graduation speaker. Thus, graduation is not analogous to a Mergens-type open forum, and the equal-access principle does not dictate the result. A school may prohibit individual speakers from leading religious exercises at graduation.

Nevertheless, because it is troublesome to leave censorship of speech in the hands of school administrators, ${ }^{115}$ a school may meet its obligations by providing its student and outside speakers with guidelines explaining why conducting religious exercises at obligatory public school events is unconstitutional under Lee $v$ Weisman. Once a school has done so, it has discharged its duty and all responsibility for the speech falls on the speaker herself. Thus, school officials need not censor each speech before it is given, or rush on stage to grab a student's microphone if she attempts to lead a prayer.

The Weisman prohibition on religious exercises at public school events does not invalidate all student-initiated religious exercises. A student-organized baccalaureate service, unlike the graduation ceremony, assembly, or football game, has the virtues of the Mergens prayer club. Attendance at the baccalaureate is entirely voluntary, it takes place during noninstructional time, and teachers and administrators need supervise the activity only minimally. Thus, Randall $v$ Pegan, in which a student group rented the school auditorium to hold a baccalaureate, was correctly decided. ${ }^{116}$ However, problems arise where the school plays some role in organizing the baccalaureate. For example, if a school permits a student group to use the normally unavailable school auditorium free of charge for a baccalaureate service, and that is the only event planned in conjunction with graduation, then the school exhibits preferential treatment-violating the Mergens equal-access principle. Such preferential treatment indicates that the forum is not truly open to all student speech, and

115 And perhaps ultimately impossible, since a speaker could always turn in an acceptable speech beforehand and then say something else at the event itself.

${ }_{116} 765$ F Supp 793 (W D NY 1991). 
Mergens prohibits such services as endorsement of religion by school officials.

Flagpole prayer also survives Establishment Clause scrutiny under Weisman because of its similarities to a student prayer club or a student-initiated baccalaureate service. Students do not have to attend flagpole prayer, teachers and administrators are not heavily involved, and other students forego no school activity by failing to attend. The major question here is whether flagpole prayer constitutes a student-initiated activity at all, given that it is organized on a national level by powerful religious groups comprised overwhelmingly of adults. Despite such concerns, one must presume student autonomy and voluntariness with a religious event like flagpole prayer. The Court's concept of voluntary attendance does not leave room for second guessing each student's individual decision to participate in a religious exercise; once a student shows up, one must presume she wishes to be there, even if she wishes to be there because her parents told her to attend. ${ }^{117}$

\section{B. Religious Speech by Individual Students}

Although the Establishment Clause limits student-initiated religious exercises to voluntary events such as prayer clubs and baccalaureates, other forms of religious expression by individual student speakers generally receive protection under Mergens. ${ }^{118}$ This principle applies when a student speaker makes an individual, private choice to speak about religion in the public schools. Thus, a valedictorian who speaks about religion, as in Guidry $v$ Broussard, does not violate the Establishment Clause simply by making reference to religious beliefs. ${ }^{119}$ Similarly, student speakers are constitutionally permitted to speak about religion at football games, assemblies, and other school events where student speech is generally allowed.

117 The rights of parents to control their children's religious training are undisputed. See Wisconsin $v$ Yoder, 406 US 205, 213-14 (1972) (holding that parents' rights to direct "religious and educational upbringing of children in their early and formulative years ha[s] a high place in our society"). See also Carey $v$ Population Services International, 431 US 678, 685 (1977) (holding that right of privacy includes childrearing and education).

118 The Supreme Court has held in another context that there is no Establishment Clause violation where the independent, private choices of individuals result in some aid to religious institutions. See Witters $v$ Washington Department of Services for Blind, 474 US 481, 487 (1986) (holding that the Establishment Clause did not preclude the state from providing financial assistance, as part of a general state program, to a blind person studying to become a pastor at a private Christian college).

11897 F2d 181 (5th Cir 1990). 
There are two possible exceptions to this rule: first, where schools violate the Mergens equal-access principle by giving preferential or biased treatment to religious speech rather than merely allowing it on a nondiscriminatory basis; and second, where religious speech completely dominates an open forum. ${ }^{120}$ Otherwise, students handing out religious literature, talking about God and reading the Bible with friends during recess, or giving reports on the life of Mohammed and the power of Islam all constitute permissible religious speech under the Establishment Clause. As a policy matter, all are part of the type of religious discourse public schools should encourage and promote, along with discourse on other cultural and religious beliefs and practices.

Religious artwork by students is also best understood as speech about religion rather than as a religious exercise, even if it represents an act of worship to the individual artist. Art reaches its audience on an artistic level and the ideas expressed by it allow debate in a way that the ideas expressed by a formal prayer at a public school event do not. However, this analysis depends once again on whether the school violates the Mergens equal-access principle by giving preferential treatment to student religious art. In Joki $v$ Board of Education of Schuylerville Central School District, for example, the school seemed to go beyond merely permitting religious speech on a nondiscriminatory basis since the crucifixion painting was one of only two student paintings exhibited in the auditorium. ${ }^{121}$ No broad spectrum of speech counteracted the appearance of endorsement by the school. Like religious speech in other areas, religious artwork allowed to dominate a forum may violate the Establishment Clause, whereas a religious painting displayed as part of a student art display does not.

Thus, the Mergens equal-access principle requires schools to afford student religious speech the same First Amendment protection that other student speech receives. As such, administrators may limit or prohibit student religious speech to maintain order in the schools. They may not give preferential treatment to religious speech or permit religious speech to dominate a forum. As we have seen, these exceptions make the analysis of any particular incident of student religious speech very fact-specific and utterly dependent on context. 


\section{CONCLUSION}

The Supreme Court's decision in Weisman indicates that student-initiated religious exercises in the public schools are constitutional only at events that students voluntarily attend in order to engage in a religious exercise. Under Mergens, on the other hand, speech about religion by individual students receives wide protection under the First Amendment's free speech guarantee, subject only to reasonable restrictions to allow schools to maintain order and pursue educational goals.

In his dissent from the First Circuit's opinion in Weisman $v$ Lee, Judge Campbell stated:

If one were to ask people what are the problems of our time, they would hardly respond that our youth and their parents are being corrupted by over-exposure to noble aspirations of this character. The common complaints are that 13 year old children are selling crack; that instead of doing homework, students are watching violent $\mathrm{TV}$; that the tolerant ideals mentioned by the rabbi are being rejected in favor destructive habits of mind and character. So what good, one might ask, is accomplished by preventing an invocation like this? ${ }^{122}$

To answer Judge Campbell, the good served by prohibiting religious exercises at public school events lies in protecting children's religious freedom and promoting tolerance of varying beliefs. One does not teach tolerance by forcing public school students to participate in or be excluded from school events in which religious exercises reflecting the majority preference are conducted. Rather, tolerance must be taught by allowing speech about religion in the public schools-in classrooms, assemblies, and graduation ceremonies, in the form of discussion or art. Such speech will encourage a healthy exchange of ideas between believers and nonbelievers, the kind of exchange a religious ceremony forced on nonbelievers never will. 


$$
\text { - }
$$

